\title{
Valuation And Market Timing In Private M\&A Transactions
}

Ted Azarmi, (E-mail: tazarmi@csulb.edu), California State University, Long Beach

Florian Eisele, (E-mail: florian.eisele@uni-tuebingen.de), Universitaet Tuebingen, Germany Christine Haecker, (E-mail: christine.haecker@uni-tuebingen.de), Universitaet Tuebingen, Germany

\begin{abstract}
The objective of this case is to teach and initiate a classroom discussion about the optimal market timing for the sale of a mid-cap privately held firm. The discussion is facilitated by a real world case example that focuses on the sale of a Little Rock, AK based plastic injection molding company with approximately $\$ 20$ million in revenues.

Theoretical and practical issues central to receiving maximum price in relation to selling at the right time are addressed. Considered are the desired time to close the deal from the owner's point of view, the time required for successful completion of the sale process, business conditions in this industry, firm-specific business conditions, and ability of agents to time this market.
\end{abstract}

This case also discusses various reasons for the sale of private companies and the effect of respective sale motives on the placement of these firms. Principally, the retirement decision by the owners of small privately held firms as the most frequent reason for the sale of these companies is explored.

\subsection{Case Description}

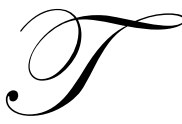

he primary subject matter of this case is investment banking and the acquisition of mid-cap privately held firms. We focus on the optimal timing of sale, the importance of industry conditions, the degree of competition amongst potential suitors, and their willingness to pay high multiples. Secondary issues examined incorporate the importance of firm-specific business conditions, such as the location and product mix of the company that is put up for sale. The effect of these issues on the determination of the sale price is also discussed. Additionally, the retirement decision of the owners of a privately held firm and its influence on the sale process is analyzed.

The case has a difficulty level that makes it appropriate for MBA and advanced undergraduate courses. The case is designed for one to two hours of instructions and is expected to require three hours of outside preparation by students.

\subsection{Valuation and Market Timing in Private M\&A Transactions}

Charles had been the owner and CEO of a small Little Rock, AK based plastic injection molding firm for 32 years. Steadily over these years, he had increased the size of his company from 10 to 210 employees while netting \$20 million in current revenues. Charles had achieved this at a personal cost of consistently working long hours over the past three decades, with an average workweek of 75 hours. His company had always been highly profitable, and he had done everything right in his business life until now.

On February 5, 2000 he decided that it was time to sell the firm. Given his age, energy level, health condition, and life style, he felt that it was the right time to retire and cash out. Fortunately, the company was highly profitable at this time. The financial statements were audited by a reputable accounting firm and were beautifully cleaned up so that there were no latent red flags or cautionary notes to scare away a potential acquirer. As a first

Readers with comments or questions are encouraged to contact the authors via email. 
step in valuing the firm, Charles commissioned an independent appraisal of the machinery and equipment (M\&E) as well as the real estate and other real property of his firm. The appraisal produced a valuation at approximately twice the current book value of these tangible assets.

Charles also discussed the sale with several investment bankers. With each banker he discussed the need to retire and his expectation to exit with an adequate pile of cash. Charles hoped to retire within six months and had a sale price of about twice the book value of his tangible assets in mind. Once he mentioned this ambition, the investment bankers advised him that his expectations regarding valuation were reasonable, but no one could guarantee what the final market price would be. However, the bankers were not optimistic about his time frame; they felt that six months was too short of a period to sell this firm. In their experience, a private company sale of this size usually took 12 to 18 months to complete, from the day when the investment banker was hired to the day when the actual deal was closed. Intent on winning a new client, Kevin, a principal with Sunbelt Advisors, in addition to mentioning the above timeline, mentioned that there are variations in sales time, in particular he emphasized that the sale process might be concluded much earlier if the company's records are well maintained. Charles was not pleased, but hesitantly resigned himself to these new circumstances, taking comfort in having a well-maintained record of healthy profits and counting on a quick sales-time based on that record. After considerable deliberation, Charles hired Sunbelt Advisors as his investment bankers.

Sunbelt Advisors assigned Kevin's associate Paula to work on this deal, as Kevin was needed for attracting additional new clients. By May 15, Paula had established a comprehensive database of potential strategic and financial buyers of plastic injection molding firms. She also created the "book" (or offering memorandum) for this deal containing detailed information on the company. After having received Charles' approval, Kevin and Paula went to market. They contacted all 180 potential buyers in their database, and initially had a fairly decent response. Approximately forty suitors signed confidentiality agreements, yet only five buyers requested the book. Most suitors knew immediately after receiving a brief overview and hearing the name of the company that they were not interested.

The molding company under consideration was highly diversified, producing products for nearly ten different industries. Strategic buyers usually are large companies looking for an add-on in their field. In this case, strategic buyers were only interested in one of the ten categories of products, but not in the other nine. Each individual category of products (market segment) netted approximately $\$ 2$ million for a total of $\$ 20$ million in revenues, so the individual pieces were too small for most buyers to efficiently consider on a standalone basis. Additionally, the location of Little Rock, AK was unattractive to buyers. The rural setting in Arkansas was considered remote from the point of view of major potential acquirers who were located in larger cities and population centers.

Both Charles and his investment bankers were surprised and disappointed with the low interest level in this deal. They had expected this well-managed, highly profitable company to sell quickly at a premium price. Responding to this adverse situation, Sunbelt Advisors intensified its efforts both by providing additional information to the existing five suitors and by continuing to solicit interest and secure additional buyers.

Kevin knew from past experiences that the merger and acquisition (M\&A) markets are cyclical with significant hot and cold spells. However, he did not discuss this issue in his solicitation of Charles' business. Soon after Sunbelt Advisors was retained for this deal, the Internet bubble burst, which caused a significant slow-down of mergers and acquisitions activity. In a relatively short period of time, most of the interested buyers had significant belttightening to do. The general sentiment had swiftly shifted from a sellers market with high multiples and an abundance of buyers to a market with lower multiples where only selective well-founded acquisitions took place.

By February 2001, one year after the sale process had begun, Sunbelt Advisors contacted all five potential buyers and requested letters of intent (LOIs) from them, setting a due date of February 9. At that deadline, the bankers received four LOIs from the five interested buyers. This was considered a good turnout considering the low level of initial interest in this firm and the cold M\&A-market conditions. However, there was little comfort in having four LOIs, as all the letters contained price offers at a much lower level than the seller's expectations. 
Initially, Charles rejected all the offers and felt angry at how little buyers were willing to pay for his outstanding company. He told Kevin that he was not going to sell after all. However, after a few weeks of discussions and considerable effort by Paula and Kevin, Charles realized that he didn't have other alternatives. He had to sell, as he felt that he eventually might be physically unable to continue to work and expected to be forced to retire in a few years.

So after six months of soul searching, Charles eventually came back to Sunbelt Advisors with much lower price expectations. Kevin restarted the sale process after Charles' return. Unfortunately, by this time, Charles' company had also been adversely affected by the general US economic slow down, a decrease in product demand, and consequences of poor industry conditions. The firm's revenue growth lessened, while profits went from outstanding to below average. Thus the EBITDA (earnings before interest, taxes, depreciation and amortization), which serves as the basis for a valuation with industry multiples, decreased significantly. Additionally, buyers lowered the multiples of EBITDA that they were willing to pay to compensate for deteriorated industry conditions. Charles faced a double whammy of a lower multiple applied to a smaller EBITDA base.

Despite declining profitability and weakening industry circumstances, Sunbelt Advisors finally received an offer that Charles regarded worth considering. It was much lower than his initial price expectations, and well below his revised price expectations, yet much higher than other existing offers for his company. American Tubes, the suitor, was the holding company for Charles' only direct competitor with a similar product mix. It appeared that a high level of expected synergies enabled American Tubes to offer a higher price for Charles' company than other buyers.

As with most deals, the offer came with strings attached. Most issues seemed to be standard issues to Kevin, as he encounters them in the majority of deals. However, there was a critical issue related to the management role that Charles was expected to play after the sale of his firm. This had to do with the fact that Charles' company had a profitable financial history, while American Tube's subsidiary had constantly been operating around breakeven point. The holding company wanted to buy Charles' company under the condition that he would stay with the new entity for three additional years, to ensure that the business would run smoothly until a suitable successor may be found.

Often CEO's hesitate selling their firm, fearing that upon the sale they may lose their job. In Charles' case the situation was reversed. He no longer wanted his top position, yet the buyer recognized that the success of the company was based on Charles' superior management. While the management team at American Tube produced poor results, Charles' firm was doing extraordinary within the same business-environment. From the buyer's point of view, the key benefit of this acquisition was the transfer of management know-how.

Consequently, this was the most important issue during the ensuing negotiations and was finally, after many weeks of bargaining, solved satisfactorily. Charles agreed to remain with the acquired company for a transition period of 18 months, and agreed to be available to the buyer as a consultant for an additional two years thereafter. Charles also agreed to serve on the board of the new company, if the buyer wished so.

After this major stumbling block was taken care of, the sale proceeded smoothly. Due diligence was performed without major difficulties. One remaining challenge was the transfer of competitively sensitive information from Charles' firm to the buyer. As expected, Charles was not willing to share sensitive data such as pricing information, proprietary new products, or customer names with American Tube before a binding purchase agreement was in place; after all, they were Charles' major competitor. Luckily, American Tube, did not need as much information as an outside financial buyer would have required. They already operated in the same business, knew who Charles' most important customers were, and had also been privy to rumors about Charles' new proprietary products. They approximately knew Charles' price level, since they had lost quite a few new contracts to him based on pricing alone.

Everything went well for a few weeks. Gradually, however, Kevin realized that American Tube was slow in responding, didn't initiate additional investigations, and seemed to be dragging its feet on the sale process on purpose. When confronted, American Tube denied the allegations, stating that it had been just too busy with other 
things. Kevin was becoming increasingly worried, especially since the continuing deteriorating state of the economy had resulted in many bankruptcies. Indeed, on July 11, 2001 Kevin's worst fears materialized when he opened the morning newspaper and read about the bankruptcy filing of American Tube.

Charles was deeply disappointed and disheartened. Paula and Kevin had worked on this deal for 14 months straight and now it was all down the drain. At least Charles had the solace of American Tube not being able to exploit competitively sensitive information. Ironically, the bankruptcy filing of his largest competitor increased Charles' customer base and gave a much-needed boost to his revenues.

Kevin carried out a quick salability analysis for Charles' company, and found that buyers were only willing to pay very low multiples at that moment. By then, all interested parties were worried about a possible recession, an industry-wide slump, and considerable reductions in revenues. Only very few companies attained their forecasted revenue growth, and even those firms felt that it was appropriate to be conservative in respect to investments and acquisitions at that time. Based on Charles' reduced EBITDA base and the poor economic conditions, the company's valuation was by now half of what he initially had expected to receive.

Frustrated, Charles resigned himself to working for another few years, until economic conditions improved and he would be able to cash out profitably. The company was his life's purpose, and he had invested too much in it. Thus he was not willing to sell it for depressed prices if he didn't absolutely have to. But he still regretted that he hadn't thought about the influence of economic conditions and the length of the sale process two years earlier. Now he felt that the next time around, he should begin the sale process when things were just starting to get good, so that he could sell at the economic peak or close to it.

\subsection{Case Questions}

1. Can one time the market in order to receive a higher value for an asset? In your answer, consider the concept of market efficiency and the valuation function of a competitive market. Start by positing a valuation mechanism, and then focus your analysis on answering the question "what gives an asset value".

2. What can a private mid-sized company do several years before the actual sale to ensure maximum price?

3. What is the rationale behind diversification, and what are its potential negative consequences?

4. Discuss the logic of confidentiality agreements, and highlight the importance of those agreements for this case.

5. Discuss the problem with "fair market" valuation and explain the influence of informational asymmetries on valuation.

6. Explain the EBITDA multiple approach for valuation and determine the appropriate current industry multiple for the acquisition of a mid-sized injection molding company.

7. Which additional valuation methods could be used? Discuss the advantages and disadvantages of each valuation method for the company that is for sale.

8. Explain the two ways in which industry conditions directly and indirectly influence acquisition prices.

9. Discuss the difference between a financial and a strategic buyer, and the consequences for the valuation of the acquisition.

10. Define the best time to sell a private company and explore when the preparation for sale should be initiated.

\section{Instructor Manual}


1. Can one time the market in order to receive a higher value for an asset? In your answer, consider the concept of market efficiency and the valuation function of a competitive market. Start by positing a valuation mechanism, and then focus your analysis on answering the question "what gives an asset value".

One valuation mechanism is based on the net present value of future cash flows of the firm. In this valuation method, the firm is viewed as a cash machine and the net present value of its projects does not change by picking a right time to sell it.

One may also consider a valuation mechanism based on demand and supply. This valuation mechanism is often used for products, not an entire firm. In this approach, a product fetches a higher price if there are more customers for it.

There is also a theoretical valuation mechanism that assigns value to an asset based on how much that asset is worth in relation to the value of other assets under different states of nature as economic uncertainty is resolved in the future.

2. What can a private mid-sized company do several years before the actual sale to enhance its market value and eventual sale price?

- $\quad$ Have financial statements audited.

- $\quad$ Strive for stable revenue growth and profitability.

- $\quad$ Do not expense owner's expenses that are unrelated to the business through the company (e.g. travel \& entertainment, company car, apartment, etc).

- $\quad$ Have machinery \& equipment, real estate, and other property appraised.

- $\quad$ Salability analysis: Find out what strategic buyers like to buy (based on preference for location, product mix, and profitability) and refocus if necessary and possible (e.g. expand a product, seek a new product to complement the existing product mix, or seek application for product in new markets).

\section{What is the rationale behind diversification, and what are its potential negative consequences?}

Diversification is the process of accumulating securities in different investments, types of industries, and risk categories in order to reduce the potential harm of loss from any one investment. One potential negative consequence might be to become mediocre in diverse areas, rather than be exceptional in one focus area. In general, diversification is recommended for investment by individuals, rather than for selection of productive processes by firms. In the case of a firm, production diversification may reduce focus in the core business area. Additionally, owners of a firm may diversify their own personal wealth by holding shares of ownership in well focused (nondiversified) firms that each benefit from specialization in their core areas of competence.

4. Discuss the logic of confidentiality agreements, and highlight the importance of those agreements for this case.

Deals break off frequently, and confidentiality agreements ensure the continued unharmed competitive position of the company that was up for sale. Without the existence of confidentiality agreements, potential harm from transferred information would be too great for most firms to undertake a sale process through an investment banker. This was especially important to our case study, since a large number of suitors looked at this highly successful business within a depressed industry and no one did eventually sign a contract to buy it.

5. Discuss the problem with fair market valuation and the existence of informational asymmetries. 
The inherent problem with fair market valuation is that it depends on an abundance of factors. Due to synergy potential, a company has a different value for different buyers. Additionally, industry conditions influence company valuation. In poor economic circumstances, buyers will pay less due to depressed buyer sentiment.

Furthermore, informational asymmetries exist between the buyer and the seller of a company. The buyer values the firm based on the information that is available to the buyer. This implies a valuation discount in relation to the state of full information disclosure. Hence, the seller has an incentive to disclose as much information as possible to decrease informational asymmetry and thus to increase the buyer's valuation. There is however a tradeoff that has to be considered carefully. Disclosure of certain company-specific information is costly, as the buyer can use this sensitive information to competitively harm the seller, particularly in the event that a deal breaks off.

6. Explain the EBITDA multiple approach for valuation and determine the appropriate current industry multiple for the acquisition of a mid-sized injection molding company.

The valuation approach for the sale of mid-sized companies is based on a debt-free basis (EBIT: earnings before interest and taxes), since it is up to the buyer to change the capital structure of the acquired company to his liking. Additionally, add-backs (depreciation and amortization) are added to EBIT. These include expenses that the buyer would not incur. The add-backs may be a significant portion of private company value, as the owners of these firms typically tend to expense their private company-unrelated expenditures through the company to minimize their-personal tax basis. Valuation multiples are therefore based on last year's EBITDA level, or the level of profitability that a buyer can reasonably expect after the acquisition. This EBITDA number is then multiplied by an industry-specific multiplier (e.g. 5.5 for an injection molding company) to net the value of the company to the buyer. The multiplier can also be regarded as the number of years it takes the investor to recoup his investment.

7. Which additional valuation methods could be used? Discuss the advantages and disadvantages of each valuation method for the company that is for sale.

- $\quad$ DCF-Approach: Difficult to estimate inputs (discount rate, growth rate), especially for private company. As always, dependent on "correct" estimation of terminal value and discount rate.

- $\quad$ Comparable Company Approach: Valuations of comparable private companies are not publicly available. Comparable listed companies might be hard to find.

- $\quad$ Comparable Transaction Approach: Pricing data on private transactions is almost impossible to attain.

- $\quad$ Real Options Approach: Suitable for young, fast-growing companies. Could result in very accurate estimate, inputs are hard to determine correctly. Small input variations result in largely different valuations.

8. Explain the two ways in which industry conditions directly and indirectly influence acquisition prices.

Industry conditions influence acquisition prices directly through multiples, which increase during good times and decrease during bad times. Acquisition prices are also influenced indirectly, since industry conditions determine the profitability of a company, and therefore have an effect on the dollar base to which the multiple will be applied to.

9. Discuss the difference between a financial and a strategic buyer, and the consequences for the valuation of the acquisition.

- $\quad$ Strategic buyer: Buyer in the same industry that can gain synergies from the acquisition.

- $\quad$ Financial buyer: Private equity group (PEG) or individual investor who solely provide the financial means 
to buy the company, have no industry expertise, require existing management to stay on, and have no synergy potential.

- Valuation: Since the strategic buyer places additional value on expected synergies, his valuation will usually be higher than the valuation of the financial buyer.

10. Define the best time to sell a private company and explore when the preparation for sale should be initiated.

The best time to sell a company is at the peak of its profitability as well as at the economic peak. The best time to be talking to buyers is when the seller can show at least one year of great earnings and profitability, and credible high growth potential for the future. The best time to initiate a sale is therefore when the buyer has been in an upturn for at least a year and a downturn is not expected in the next 12 to 18 months. However, a valuable firm that is generating positive net present value future cash flows should theoretically sell at the present value of expected future earnings in a well-functioning market.

Notes 
